\title{
Effects of carbonate and Fe(II) on As(III) adsorption and oxidation on hydrous manganese oxide
}

\author{
Z.X. Zhao ${ }^{1}$, S.F. Wang ${ }^{2}$ \& Y.F. Jia ${ }^{2}$ \\ ${ }^{1}$ College of Chemistry and Chemical Engineering, Xinjiang Normal University, Urumqi, China \\ ${ }^{2}$ Institute of Applied Ecology, Chinese Academy of Sciences, Shenyang, China
}

\begin{abstract}
Manganese oxide plays an important role in redox transformation of arsenic in the aquatic environment. High levels of carbonate and $\mathrm{Fe}(\mathrm{II})$ were found as major coexistent ions with arsenic, but their influences on oxidation of arsenite $(\mathrm{As}(\mathrm{III}))$ to arsenate $(\mathrm{As}(\mathrm{V}))$ by manganese oxide were not fully understood. This work researched oxidation of As(III) on hydrous manganese oxide (HMO) and investigated the effects of carbonate and $\mathrm{Fe}(\mathrm{II})$.
\end{abstract}

\section{INTRODUCTION}

Manganese oxide is an important oxidant for the transformation of arsenic speciation in the aquatic environment (Ying et al., 2012). It was also proposed as an oxidant for the treatment of arsenic contaminated groundwater (Xu et al., 2011). As(III) oxidation by manganese oxide may be influenced by coexistent ions, such as $\mathrm{Ca}$ (II) and $\mathrm{Zn}$ (II) (Lafferty et al., 2011). In anaerobic groundwater condition, the concentration of Fe(II) was higher than that of heavy metals (Appelo et al., 2002). However, little is known about its influence on $\mathrm{As}$ (III) oxidation by manganese oxide. Fe(II) was reactive and readily oxidized to ferric oxide by $\mathrm{MnO}_{2}$ (Han et al., 2011), hence may compete with As(III) for the oxidant.

\section{METHODS/EXPERIMENTAL}

\subsection{As(III) adsorption and oxidation}

As(III) adsorption and oxidation experiments were performed by contacting As(III) solution with HMO suspensions in batch reactors at $20^{\circ} \mathrm{C}$, with the background electrolyte of $0.02 \mathrm{~mol} \mathrm{~L}^{-1} \mathrm{NaCl} .0 .1 \mathrm{~mL}$ of $1 \mathrm{~g} \mathrm{~L}^{-1} \mathrm{As}(\mathrm{III})$ stock solution was added to $50 \mathrm{~mL}$ HMO suspension with the $\mathrm{pH}$ pre-adjusted to target value and the initial concentration of $2 \mathrm{mg} \mathrm{L}^{-1}$ $\mathrm{As}(\mathrm{III})$ was obtained. The $\mathrm{pH}$ of the mixture was maintained constant using $0.05 \mathrm{~mol} \mathrm{~L}^{-1} \mathrm{HCl}$ and/or $\mathrm{NaOH}$ solutions.

\subsection{Determination of arsenic and iron concentrations}

The concentrations of $\mathrm{As}(\mathrm{III})$ and $\mathrm{As}(\mathrm{T})$ were measured using hydride-generation atomic fluorescence spectrophotometer (AFS-2202E, Haiguang Corp., Beijing) with a detection limit of $0.01 \mu \mathrm{g} \mathrm{L}^{-1}$ and duplication analysis agreed within $5 \%$. The concentration of $\mathrm{Mn}$ (II) was determined using a flame atomic absorption spectrophotometer (AA240, Varian) with a detection limit of $0.05 \mathrm{mg} \mathrm{L}^{-1}$ and duplication analysis agreed within $7 \%$.

\section{RESULTS AND DISCUSSION}

\subsection{Kinetic studies of As(III) adsorption and oxidation on $H M O$}

The effect of carbonate and Fe(II) on As(III) adsorption and oxidation on hydrous manganese oxide was observed in kinetic studies under $\mathrm{Mn} / \mathrm{As}=8.5$ and $\mathrm{pH}=7.0$ conditions. Adsorption and oxidation of $\mathrm{As}(\mathrm{III})$ in $\mathrm{HMO}$ system with carbonate and $\mathrm{Fe}(\mathrm{II})$ was compared with pure HMO system (see Fig. 1). The concentrations of $\mathrm{As}(\mathrm{III})$ and $\mathrm{As}(\mathrm{V})$ in aqueous and solid phase in pure HMO system without coexistent carbonate and Fe(II) were showed in Figure 1. The concentration of As(III) in aqueous phase dropped from $2.0 \mathrm{mg} \mathrm{L}^{-1}$ to $1.7 \mathrm{mg} \mathrm{L}^{-1}$ within $1 \mathrm{~h}$ and decreased slowly to a stable level $\left(\sim 1.5 \mathrm{mg} \mathrm{L}^{-1}\right)$ after $48 \mathrm{~h}$ reaction. The concentration of $\mathrm{As}(\mathrm{V})$ in aqueous phase increased to $0.25 \mathrm{mg} \mathrm{L}^{-1}$ after $48 \mathrm{~h}$ reaction. In solid phase, few of As(III) could be detected during $48 \mathrm{~h}$ reaction time. The concentration of aqueous $\operatorname{As}(\mathrm{V})$ increased to $0.2 \mathrm{mg} \mathrm{L}^{-1}$ within $1 \mathrm{~h}$ and reached to $0.25 \mathrm{mg} \mathrm{L}^{-1}$ after $48 \mathrm{~h}$ reaction time. The $\mathrm{As}(\mathrm{V})$ in solid increased to $0.3 \mathrm{mg} \mathrm{L}^{-1}$ after $48 \mathrm{~h}$ reaction time. The results indicated that $30 \%$ of added As(III) was oxidized to As(V). About $55 \%$ of oxidized As(V) was adsorbed and few of As(III) was adsorbed on HMO. This implied that at the neutral $\mathrm{pH}$ HMO has strong 


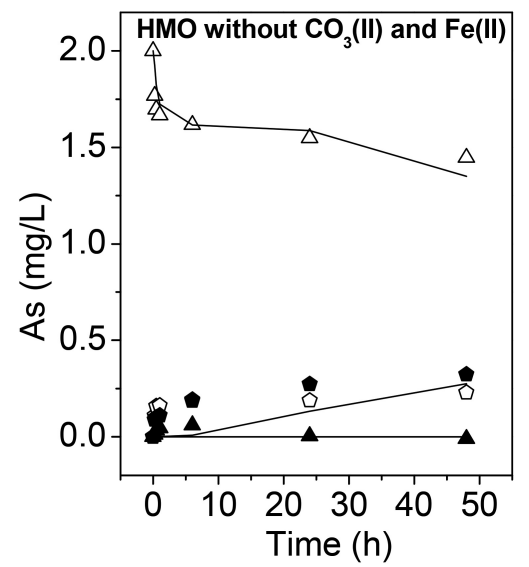

Figure 1. Distribution of $\mathrm{As}(\mathrm{III})$ and $\mathrm{As}(\mathrm{V})$ (triangle and pentagon respectively) in aqueous and solid phase (open and solid respectively) by contacting As(III) with HMO as a function of time at $\mathrm{Mn} / \mathrm{As}=8.5$ and $\mathrm{pH}$ 7.0.

oxidation capacity for As(III) and high adsorption capacity for $\mathrm{As}(\mathrm{V})$.

Carbonate and $\mathrm{Fe}(\mathrm{II})$ showed distinct effect on kinetics of As(III) adsorption and oxidation on HMO. The addition of carbonate only slightly increased $\mathrm{As}(\mathrm{V})$ adsorption at the beginning of the reaction. The addition of $\mathrm{Fe}(\mathrm{II})$ increased As(III) oxidation significantly and $60 \%$ of $\mathrm{As}(\mathrm{III})$ was oxidized to $\mathrm{As}(\mathrm{V})$. More $\mathrm{As}(\mathrm{III})$ and $\mathrm{As}(\mathrm{V})$ were adsorbed on $\mathrm{HMO}$ in the presence of $\mathrm{Fe}(\mathrm{II})$. The maximum value of $\mathrm{As}$ (III) concentration in solid phase at the beginning of the reaction indicated that adsorption and oxidation of As(III) on HMO were competitive process, which controlled the concentrations of $\mathrm{As}(\mathrm{III})$ and $\mathrm{As}(\mathrm{V})$ in aqueous and solid phase. The addition of carbonate and $\mathrm{Fe}(\mathrm{II})$ at the same time mainly exhibited the effect of $\mathrm{Fe}(\mathrm{II})$ on adsorption and oxidation of As(III) on HMO.

\subsection{Equilibrium studies under acidic pH condition}

The effect of carbonate and Fe(II) on As(III) adsorption and oxidation on hydrous manganese oxide was observed in equilibrium studies under $\mathrm{pH}=3.0$ condition. Adsorption and oxidation of As(III) in HMO system with carbonate and $\mathrm{Fe}$ (II) was compared with pure HMO system (see Fig. 2). The concentrations of $\mathrm{As}(\mathrm{III})$ and $\mathrm{As}(\mathrm{V})$ in aqueous and solid phase in pure HMO system without coexistent carbonate and $\mathrm{Fe}(\mathrm{II})$ are shown in Figure 2. Under $\mathrm{pH}=3.0$ condition, both of the As(III) in aqueous and solid phase could be ignored. The concentration of $\mathrm{As}(\mathrm{V})$ in aqueous and solid phase increased to 1.4 and $0.6 \mathrm{mg} \mathrm{L}^{-1}$ at $\mathrm{Mn} / \mathrm{As}$ ratio is 68 . This indicated that the influence of $\mathrm{pH}$ on As (III) oxidation was great. Under acidic condition As (III) oxidation increased remarkably even at low $\mathrm{Mn} / \mathrm{As}$ ratio and presented great independence

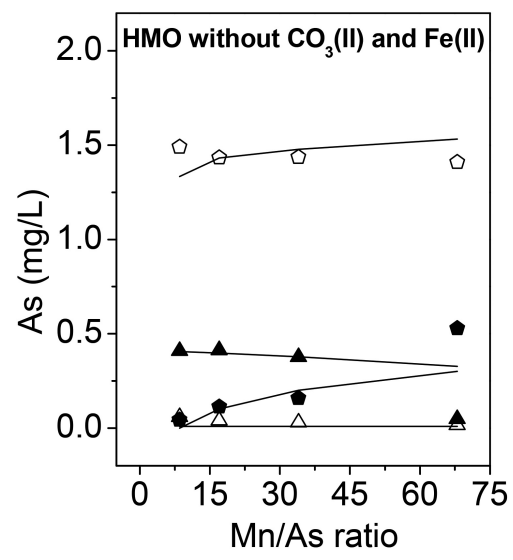

Figure 2. Distribution of $\mathrm{As}(\mathrm{III})$ and $\mathrm{As}(\mathrm{V})$ (triangle and pentagon respectively) in aqueous and solid phase (open and solid respectively) by contacting As(III) with $\mathrm{HMO}$ as a function of $\mathrm{Mn} / \mathrm{As}$ ratio at $\mathrm{pH}$ 3.0. Solid lines represent model results.

with $\mathrm{Mn} / \mathrm{As}$ ratio. The reaction was largely driven by the proton concentration (Villalobos et al., 2014). The produced $\mathrm{As}(\mathrm{V})$ existed primarily in aqueous phase and presented more in solid phase at higher $\mathrm{Mn} / \mathrm{As}$ ratios.

\subsection{Equilibrium studies under neutral pH condition}

The effect of carbonate and Fe(II) on As(III) adsorption and oxidation on hydrous manganese oxide was observed in equilibrium studies under $\mathrm{pH}=7.0$ condition. Adsorption and oxidation of As(III) in HMO system with carbonate and $\mathrm{Fe}(\mathrm{II})$ was compared with pure HMO system (see Fig. 3). The concentrations of $\mathrm{As}(\mathrm{III})$ and $\mathrm{As}(\mathrm{V})$ in aqueous and solid phase in pure HMO system without coexistent carbonate and Fe(II) are presented in Figure 3. Under $\mathrm{pH}=7.0$ condition, As(III) concentration in aqueous phase decreased to $0.8 \mathrm{mg} \mathrm{L}^{-1}$ at higher $\mathrm{Mn} / \mathrm{As}$ ratio. The concentration of $\mathrm{As}(\mathrm{V})$ in aqueous and solid phase increased to 0.8 and $0.5 \mathrm{mg} \mathrm{L}^{-1}$ at $\mathrm{Mn} / \mathrm{As}$ ratio is 68 . Under neutral condition As (III) oxidation increased with $\mathrm{Mn} / \mathrm{As}$ ratio and presented great dependence with $\mathrm{Mn} / \mathrm{As}$ ratio. Half of produced $\mathrm{As}(\mathrm{V})$ existed in aqueous phase at all four $\mathrm{Mn} / \mathrm{As}$ ratios.

In HMO system with carbonate, fewer of $\mathrm{As}(\mathrm{V})$ adsorbed in solid phase than that in pure HMO system at higher $\mathrm{Mn} / \mathrm{As}$ ratio. This was consistent with the results under acidic $\mathrm{pH}$ condition. In HMO system with $\mathrm{Fe}(\mathrm{II})$, more As (III) was oxidized to As(V) than that in pure HMO system. Moreover, more As(III) and $\mathrm{As}(\mathrm{V})$ was adsorbed in solid phase than that in pure HMO system. This suggested that addition of Fe(II) could increased As(III) oxidation and As(III) and $\mathrm{As}(\mathrm{V})$ adsorption significantly. There were two reason for these results. One reason was that $\mathrm{Fe}(\mathrm{II})$ was 


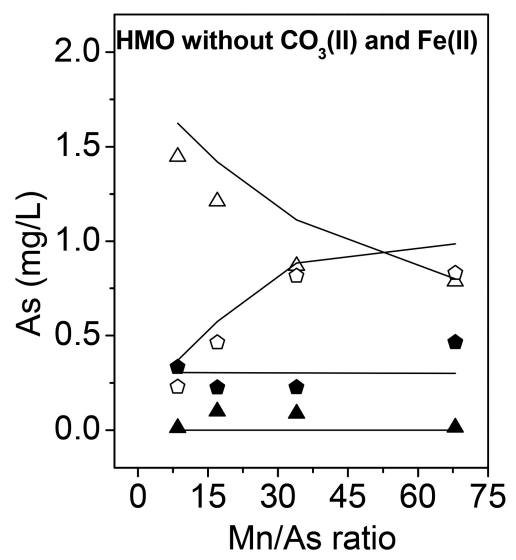

Figure 3. Distribution of As(III) and As(V) (triangle and pentagon respectively) in aqueous and solid phase (open and solid respectively) by contacting As(III) with HMO as a function of $\mathrm{Mn} / \mathrm{As}$ ratio at $\mathrm{pH} 7.0$.

oxidized to $\mathrm{Fe}(\mathrm{III})$ oxide at neutral $\mathrm{pH}$ and supplied new sites for As(V) adsorption (Ying et al., 2012).

\section{CONCLUSIONS}

(1) Addition of $\mathrm{Fe}(\mathrm{II})$ decreased oxidation of As(III) on HMO at acidic $\mathrm{pH}$, while increased As(III) oxidation at neutral and basic $\mathrm{pH}$. This indicated that different mechanisms may be involved in the presence of $\mathrm{Fe}(\mathrm{II})$. Formation of amorphous ferric arsenate or ferric oxide at different $\mathrm{pH}$ is responsible for this.

(2) Carbonate ions decreased $\mathrm{As}(\mathrm{V})$ adsorption at neutral $\mathrm{pH}$ under higher $\mathrm{Mn} / \mathrm{As}$ ratio. Precipitation of $\mathrm{MnCO}_{3}$ was the major reason because its existence on $\mathrm{HMO}$ decreased $\mathrm{As}(\mathrm{V})$ adsorption on HMO. Formation of $\mathrm{MnCO}_{3}$ also immobilized manganese and decreased the concentration of $\mathrm{Mn}(\mathrm{II})$ in aqueous phase. This has important environmental implications in protecting the groundwater from secondary manganese contamination during remediation of arsenic contaminated groundwater using HMO.

\section{ACKNOWLEDGEMENTS}

This work was financially supported by the National Natural Science Foundation of China (NO. 41203071). We sincerely thank Prof. Shiqiang Wei and his students at NSRL and Prof. Yidong Zhao and his students at BSRL for their assistances with XANES measurements.

\section{REFERENCES}

Appelo, C.A.J., Van der Weiden, M.J.J., Tournassat, C. \& Charlet, L. 2002. Surface complexation of ferrous iron and carbonate on ferrihydrite and the mobilization of arsenic. Environ. Sci. Technol. 36(14): 3096-3103.

Han, X., Li, Y.L. \& Gu, J.D. 2011. Oxidation of As(III) by $\mathrm{MnO} 2$ in the absence and presence of $\mathrm{Fe}(\mathrm{II})$ under acidic conditions. Geochim. Cosmochim. Acta 75(2): 368-379.

Lafferty, B., Ginder-Vogel, M.A. \& Sparks, D.L. 2011. Arsenite oxidation by a poorly-crystalline manganese oxide. 3 . arsenic and manganese desorption. Environ. Sci. Technol. 45(21): 9218-9223.

Villalobos, M., Escobar-Quiroza, I. N. \& Salazar-Camachoa, C. 2014. The influence of particle size and structure on the sorption and oxidation behavior of birnessite: I. Adsorption of As(V) and oxidation of As(III). Geochimi. Cosmochimi. Acta 125: 564-581.

Xu, W., Wang, H., Liu, R., Zhao, X. \& Qu, J. 2011. Arsenic release from arsenic-bearing Fe-Mn binary oxide: Effects of Eh condition. Chemosphere 83(7): 1020-1027.

Ying, S.C., Kocar, B.D. \& Fendorf, S. 2012. Oxidation and competitive retention of arsenic between iron- and manganese oxides. Geochimi. Cosmochim. Acta 96(11): 294-303. 